\title{
Estrogenic activity, chemical levels and health risk assessment of municipal distribution point water from Pretoria and Cape Town, South Africa
}

Magdalena Catherina Van Zijl ${ }^{\mathrm{a}, \mathrm{b}}$, Natalie Hildegard Aneck-Hahn ${ }^{\mathrm{a}, \mathrm{b}^{\star}}$, Pieter Swart ${ }^{\mathrm{c}}$, Stefan Hayward ${ }^{c}$, Bettina Genthe ${ }^{d}$, Christiaan De Jager ${ }^{a}$

${ }^{a}$ School of Health Systems and Public Health, University of Pretoria, Private Bag X323, Arcadia, 0007, Pretoria, South Africa

${ }^{\mathrm{b}}$ Department of Urology, Steve Biko Academic Hospital, Private Bag X323, Arcadia, 0007, Pretoria, South Africa

${ }^{c}$ Central Analytical Facility, Department of Biochemistry, University of Stellenbosch, Private Bag X1, Matieland, 7602, South Africa

${ }^{d}$ Council for Scientific and Industrial Research: Natural Resources and the Environment, PO Box 320, Stellenbosch, 7599, South Africa

\section{E-mail addresses:}

Natalie H Aneck-Hahn - natalie.aneck-hahn@up.ac.za

Magdalena C van Zijl - catherina.vanzijl@up.ac.za

Pieter Swart - pswart@sun.ac.za

Stefan Hayward - stefanh@sun.ac.za

Bettina Genthe - bgenthe@csir.co.za

Christiaan de Jager - tiaan.dejager@up.ac.za

* Corresponding author: Magdalena C van Zijl, Department of Urology, University of Pretoria, Private Bag X323, Arcadia, 0007, Pretoria, South Africa

Tel.: +27 12354 1536; fax: +27 123542500 E-mail: catherina.vanzij|@up.ac.za 


\section{Highlights}

- Estrogenic activity was detected in Pretoria and Cape Town drinking water.

- Estrogens, bisphenol-A and phthalates were detected in distribution point water.

- Distribution point water is associated with acceptable health and carcinogenic risks.

\section{Abstract:}

Endocrine disrupting chemicals (EDCs) are ubiquitous in the environment and have been detected in drinking water from various countries. Although various water treatment processes can remove EDCs, chemicals can also migrate from pipes that transport water and contaminate drinking water. This study investigated the estrogenic activity in drinking water from various distribution points in Pretoria (City of Tshwane) ( $n=40)$ and Cape Town ( $n=40)$, South Africa, using the recombinant yeast estrogen screen (YES) and the T47D-KBluc reporter gene assay. The samples were collected seasonally over four sampling periods. The samples were also analysed for bisphenol A (BPA), nonylphenol (NP), di(2-ethylhexyl) adipate (DEHA), dibutyl phthalate (DBP), di(2-ethylhexyl) phthalate (DEHP), diisononylphthalate (DINP), $17 \beta$-estradiol $\left(E_{2}\right)$, estrone $\left(E_{1}\right)$ and ethynylestradiol $\left(E_{2}\right)$ using ultraperformance liquid chromatography-tandem mass spectrophotometry (UPLCMS/MS). This was followed by a scenario based health risk assessment to assess the carcinogenic and toxic human health risks associated with the consumption of distribution point water. None of the water extracts from the distribution points were above the detection limit in the YES bioassay, but the EEq values ranged from 0.002 to $0.114 \mathrm{ng} / \mathrm{L}$ using the T47D-KBluc bioassay. BPA, DEHA, DBP, DEHP, DINP $\mathrm{E}_{1}$, $\mathrm{E}_{2,}$, and $\mathrm{EE}_{2}$ were detected in distribution point water samples. NP was below the 
detection limit for all the samples. The estrogenic activity and levels of target chemicals were comparable to the levels found in other countries. Overall the health risk assessment revealed acceptable health and carcinogenic risks associated with the consumption of distribution point water.

\section{Keywords:}

Endocrine disrupting chemicals (EDCs); estrogenic activity; bisphenol-A; estrogens; phthalates; health risk assessment

\section{Abbreviations:}

$\begin{array}{ll}\text { ADD } & \text { Average daily dose } \\ \beta & \text { Oral potency factor } \\ \text { BPA } & \text { Bisphenol A } \\ \text { BW } & \text { Body weight } \\ \text { medium }_{\text {m }} & \text { Concentration of substance in water } \\ \text { CPRG } & \text { Chlorophenol red- } \beta \text {-D-galactopyranoside } \\ \text { DBP } & \text { Dibutyl phthalate } \\ \text { dBPA } & \text { Deuterated BPA } \\ \text { DCM } & \text { Dichloromethane } \\ \text { DEHA } & \text { Di(2-ethylhexyl) adipate } \\ \text { DEHP } & \text { Di(2-ethylhexyl) phthalate } \\ \text { DINP } & \text { Diisononyl phthalate } \\ \text { dl } & \text { Detection limit } \\ E_{1} & \text { Estrone } \\ E_{2} & 17 \beta \text {-Estradiol }\end{array}$


Exposure duration

EDCs Endocrine disrupting chemicals

$\mathrm{EE}_{2}$

Ethynylestradiol

EEq

Estradiol equivalents

FBS

Fetal bovine serum

$\mathrm{HQ} \quad$ Hazard quotient

IR

Daily intake rate

LADD

Lifetime average daily dose

Lft

Lifetime

loq

Level of quantification

MtBE

Methyl tertiarybutyl ether

NP

Nonylphenol

PBS

Phosphate buffered saline

PVC

Polyvinyl chloride

RfD

Reference dose

SPE

Solid phase extraction

UPLC-MS/MS Ultra-performance liquid chromatography-tandem mass spectrophotometry

USEPA

United States Environmental Protection Agency

WHO

World Health Organization

YES

Yeast estrogen screen 


\section{Introduction}

The demand for the supply of clean water is increasing due to the continuing human population growth (Loos et al., 2007). However, population growth and urbanization is associated with a reduction in water quality with industrial and agricultural activities contributing to the contamination of water sources (Guillette and Crain, 2000; Sumpter, 2005; Falconer et al., 2006). Some of these contaminants are endocrine disruptors that have the potential to cause adverse health effects in humans.

Endocrine disrupting chemicals (EDCs) can enter the aquatic environment via direct discharge into water, effluents from sewage treatment plants, leaching (e.g. leakage from septic tanks and landfill sites), storm water runoff and accidental spills (Slabbert et al., 2008; Burkhardt-Holm, 2010). Many environmental EDCs are estrogenic and estrogenic activity was found at varying concentrations in raw and treated water in various countries, including South Africa (Slabbert et al., 2008; Burkhardt-Holm, 2010; Genthe et al., 2010; Manickum and John, 2014). Natural and synthetic estrogens, bisphenol-A (BPA), nonylphenol (NP) and short chain phthalates are some of the substances that contribute to the estrogenic load in water bodies and may cause adverse effects in aquatic organisms (Kunz et al., 2015).

Natural hormones, including estrogens, can be released into the environment via sewage effluent and from such sources such as agricultural and pharmaceutical activities (Falconer et al., 2006; Slabbert et al., 2008; Burkhardt-Holm, 2010). Estrogenic potencies of natural and synthetic estrogens are three to seven orders of magnitude greater than the potencies of other EDCs, making them the major contributor to e strogenic activity in environmental water (Desbrow et al., 1998; 
Tanaka et al., 2001; Nakada et al., 2004; Racz and Goel, 2010). Although natural estrogens are essential for normal development and reproduction, natural and synthetic estrogens are also known human carcinogens (Metzler et al., 1998).

BPA may be present in some plastics, polyvinyl chloride (PVC) products and thermal receipts (Biederman et al., 2010; Rochester, 2013). These products are often disposed of in landfill sites. Compounds, like BPA, can enter waterways through leachate from landfill sites (Kawagoshi et al., 2003). BPA exposure is associated with adverse reproductive and developmental effects, metabolic disease, disruption of thyroid function and immune disorders (Rochester, 2013). NP is used in the manufacturing of industrial and household surfactants and plastics. It is introduced to the environment mainly through industrial effluents and wastewater discharges (Loyo-Rosales et al., 2004; Burkhardt-Holm, 2010). In addition to the steroid hormones, NP may contribute substantially to the estrogenic activity in aquatic environments (Ternes et al., 1999b; Johnson et al., 2005; Galli and Braun, 2008). The endocrine disruptive effects of NP include feminization of aquatic organisms and decreased male fertility (Soares et al., 2008).

Phthalates are used as plasticisers in PVC plastics and are found in numerous consumer products. Phthalates are not covalently bonded to the plastics in which they are used, and are therefore continuously being released from the products (Heudorf et al., 2007). Contamination of waterways may therefore be through leachate from landfill sites (Burkhardt-Holm, 2010). Phthalates are associated with increased adiposity and insulin resistance (Grun and Blumberg, 2009), decreased levels of sex hormones (Pan et al., 2006) and other adverse effects on the human 
reproductive system (Hauser and Calafat, 2005; Sax, 2010) as well as attention deficit hyperactivity disorder and reduced IQ scores in children (Cho et al., 2010). Di(2-ethylhexyl) adipate (DEHA) is used as an alternative to phthalates in flexible PVC products (Ghisari and Bonefeld-Jorgensen, 2009) and has been classified by the United States Environmental Protection Agency (USEPA) as a possible human carcinogen (USEPA, 1992).

EDCs can potentially be found in drinking water if drinking water treatment processes are not effectively removing these environmental water contaminants from the source water. Water treatment process technology differs at different water treatment plants and various steps in the water treatment process can remove estrogenic activity to some degree (Slabbert et al., 2008; Burkhardt-Holm, 2010). Treatment options to remove EDCs include separation processes, adsorption and biological and chemical conversion (Chang et al., 2009). Each treatment method has its own limitations and benefits to remove EDCs. Although water treatment processes can be effective in removing EDCs from drinking water, chemicals might also migrate from the water lines/pipes that transport water to distribution points and to the home, thereby adding to the contamination of the drinking water. NP, phthalate esters and BPA can migrate from reservoirs and pipes containing polyethylene plastic, epoxy resins or paints (Romero et al., 2002; Casajuana and Lacorte, 2003).

Limited information is available on estrogenic activity and levels of EDCs in drinking water from South Africa. This study investigated the estrogenic activity in drinking water from various distribution points in Pretoria (City of Tshwane) and Cape Town, 
South Africa. The drinking water samples were also analysed for selected target chemicals that included natural and synthetic estrogens, BPA, NP, selected phthalates and DEHA, followed by a scenario based human health risk assessment.

\section{Materials and Methods}

\subsection{Sample collection and extraction}

Treated drinking water samples were collected seasonally over four sampling periods from two study areas, namely Pretoria (City of Tshwane) and Cape Town. Both are larger, well-functioning municipalities, but in different geographical areas of South Africa. The main water distribution points in Pretoria and Cape Town were identified and ten representative sampling sites per city were selected. Samples were taken from selected distribution points and not from individual homes (i.e. not point of use). These points rather than points in private homes were selected in order to prevent the possibility of confounding factors in the form of the different types of piping used in private homes and to provide an indication of the quality of water supplied by the water service provider. Table 1 summarizes the treatment processes that were applied to the water from each distribution point. 
Table 1: Treatment processes applied to water samples from distribution points

\begin{tabular}{|c|c|}
\hline Site & Treatment processes \\
\hline PTA01 & Dose flocculant, sedimentation, dissolved air flotation, filtration, chlorination \\
\hline PTA02 & $\begin{array}{l}\text { Pre-oxidation with } \mathrm{KMnO}_{4} \text { or ozone, dose flocculant, dissolved air flotation, sedimentation, } \\
\text { filtration, granular activated carbon, chlorination }\end{array}$ \\
\hline PTA03 & Fountain water from 2 fountains, chlorination only \\
\hline PTA04 & Fountain water from PTA03, chlorination only \\
\hline PTA05 & Mix of PTA06 and PTA07 water \\
\hline PTA06 & $\begin{array}{l}\text { Dose flocculant, dissolved air flotation combined with filtration, granular activated carbon, } \\
\text { chlorination }\end{array}$ \\
\hline PTA07 & Dose flocculant, sedimentation, filtration, granular activated carbon, chlorination \\
\hline PTA08 & Fountain water, chlorination only \\
\hline PTA09 & Dose flocculant, sedimentation, filtration, chlorination \\
\hline PTA10 & Dose flocculant, dissolved air flotation, filtration, chlorination \\
\hline СРT01 & Water from a combination of treatment plants, mostly CPT10 \\
\hline СРТ02 & $\begin{array}{l}\text { Coagulation and } \mathrm{pH} \text { adjustment, powder activated carbon, flocculation, settlement, } \\
\text { filtration, stabilisation, chlorination }\end{array}$ \\
\hline СРТ03 & $\begin{array}{l}\text { Coagulation and } \mathrm{pH} \text { adjustment, powder activated carbon, flocculation, settlement, } \\
\text { filtration, stabilisation, chlorination }\end{array}$ \\
\hline СРТ04 & $\begin{array}{l}\text { Coagulation and } \mathrm{pH} \text { adjustment, flocculation, settlement, filtration, stabilisation, } \\
\text { chlorination }\end{array}$ \\
\hline СРТ05 & Water from a combination of treatment plants, mostly CPT02 \\
\hline СРТ06 & $\begin{array}{l}\text { Coagulation and } \mathrm{pH} \text { adjustment, flocculation, settlement, filtration, stabilisation, } \\
\text { chlorination }\end{array}$ \\
\hline СРТ07 & $\begin{array}{l}\text { Coagulation and } \mathrm{pH} \text { adjustment, flocculation, settlement, filtration, stabilisation, } \\
\text { chlorination }\end{array}$ \\
\hline СРТ08 & Water from a combination of treatment plants, including СРТ03 \\
\hline СРТ09 & $\mathrm{pH}$ adjustment, ion-exchange softening, chlorination \\
\hline CPT10 & $\begin{array}{l}\text { Coagulation and } \mathrm{pH} \text { adjustment, powder activated carbon, flocculation, settlement, } \\
\text { filtration, stabilisation, chlorination }\end{array}$ \\
\hline
\end{tabular}

Water samples were collected in triplicate in $1 \mathrm{~L}$ glass bottles, prepared by rinsing the bottles with HPLC grade methanol (Merck, Darmstadt, Germany). The lids of the bottles were lined with tin foil to prevent the samples from coming into contact with the plastic lids, which can be a possible source of EDC contamination. The $\mathrm{pH}$ of the water samples were adjusted to 3 using $32 \%$ hydrochloric acid (Merck, Darmstadt, Germany). The water was stored at $4^{\circ} \mathrm{C}$ in the dark until it was extracted. To account for seasonal variations in levels of EDCs, samples were collected from the 
identified sites in October 2013 (spring), January 2014 (summer), April 2014 (autumn) and July 2014 (winter).

Water samples were extracted by solid phase extraction (SPE) using Oasis HLB 200 mg cartridges (Waters, Milford, Massachusetts, USA) according to the method recommended by the supplier for EDCs in water samples (Waters, 2009). SPE cartridges were pre-conditioned with $5 \mathrm{~mL} 10 \%$ methanol in methyl tertiarybutyl ether (MtBE) (Sigma-Aldrich, St. Louis, MO, USA), followed by $3 \mathrm{~mL}$ methanol. The cartridges were equilibrated with $3 \mathrm{~mL}$ double-distilled water, before the samples were loaded ( $1 \mathrm{~L} /$ cartridge). The cartridges were washed with $3 \mathrm{~mL} 5 \%$ methanol in double-distilled water and dried. The samples were eluted from the cartridges using $6 \mathrm{~mL}$ 10\% methanol in MtBE. Throughout the extraction procedure the flow rate was never allowed to exceed $10 \mathrm{~mL} /$ minute and care was taken not to let the cartridge run dry until the whole sample volume passed through the cartridge. Glass serological pipettes were used for all solvents and disposable serological pipettes were used for the samples. After elution, the solvent was evaporated to dryness at $37^{\circ} \mathrm{C}$ under a gentle nitrogen stream. The sample residue was reconstituted in $1 \mathrm{~mL}$ HPLC grade ethanol (Merck, Darmstadt, Germany) for analysis in the bioassays (concentration factor of $1000 \mathrm{x}$ ). A separate extract of each sample was derivatized for ultra-performance liquid chromatography-tandem mass spectrophotometry (UPLC-MS/MS) analysis. Reconstituted samples were stored at $-20^{\circ} \mathrm{C}$. 


\subsection{Bioassays for estrogenic activity}

\subsubsection{Recombinant yeast estrogen screen (YES)}

The YES bioassay was developed in the Genetics Department at Glaxo and is described in detail in Routledge and Sumpter (1996). The genetically modified Sacchromyces cerevisiae yeast strain was obtained from Prof JP Sumpter's laboratory, in the Department of Biology and Biochemistry, Brunel University, Uxbridge, Middlesex in the United Kingdom. Preparation of the growth medium and the YES bioassay was performed according to standard assay procedures (Routledge and Sumpter, 1996; De Jager et al., 2011). In short, yeast cells were incubated overnight in a rotating water bath $\left(28^{\circ} \mathrm{C}, 155 \mathrm{upm}\right)$ until turbid. Serial dilutions (1:2) of the extracts, $17 \beta$-estradiol $\left(\mathrm{E}_{2}\right)$ positive control (Sigma-Aldrich, St. Louis, MO, USA) ranging from $1 \times 10^{-8} \mathrm{M}$ to $4.8 \times 10^{-12} \mathrm{M}$ and vehicle control (ethanol) were prepared in ethanol. Aliquots $(10 \mu \mathrm{L})$ were transferred to triplicate 96 well micro-titre plates (Thermo Fisher Scientific, Denmark). The ethanol was allowed to evaporate to dryness before $200 \mu \mathrm{L}$ assay medium containing yeast and the chromogenic substrate chlorophenol red- $\beta$-d-galactopyranoside (CPRG) (Roche Diagnostics, Mannheim, Germany) were dispensed into each sample well. The plates were incubated in a naturally ventilated incubator at $32{ }^{\circ} \mathrm{C}$ for 3 to 5 days. On day 3, 4 and 5 the absorbance was measured on a Multiskan Spectrum 96-well plate reader (Thermo Fisher Scientific, Vantaa, Finland), at $540 \mathrm{~nm}$ (for colour) and 620 $\mathrm{nm}$ (for turbidity, as an indicator of yeast cell growth). Samples were considered cytotoxic at concentrations where the absorbance of the sample at $620 \mathrm{~nm}$ were less than the average absorbance elicited by the solvent control (blank) minus three times the standard deviation. The following equation was applied to correct for turbidity: 
Corrected value $=$ test abs $(540 \mathrm{~nm})-[$ test abs $(620 \mathrm{~nm})-$ median blank abs $(620$ $\mathrm{nm})]$

The detection limit of the yeast assay was calculated as the absorbance elicited by the solvent control plus three times the standard deviation. The $\mathrm{E}_{2}$ standard curve was fitted (sigmoidal function, variable slope) using Graphpad Prism (version 4), and the estradiol equivalents $(\mathrm{EEq})$ of water samples with three or more points above the detection limit were interpolated from the standard curve and corrected with the appropriate dilution factor for each sample.

\subsubsection{T47D-KBluc reporter gene bioassay}

The T47D-KBluc reporter gene bioassay was developed by the USEPA to screen environmental samples and chemicals for estrogenic and anti-estrogenic activities and is described in detail in Wilson et al. (2004). The T47D-KBluc cells were purchased from the American Type Culture Collection (ATCC, Manassas, Virginia, USA). The assay was performed according to standard assay procedures (Wilson et al., 2004; De Jager et al., 2011). T47D-KBluc cells were maintained in RPMI growth media (Sigma-Aldrich, St. Louis, MO, USA) supplemented with $2.5 \mathrm{~g} / \mathrm{L}$ glucose (Merck, Darmstadt, Germany), 10 mM HEPES, 1 mM sodium pyruvate, $1.5 \mathrm{~g} / \mathrm{L}$ sodium bicarbonate (Gibco, Life Technologies Corporation, Paisley, UK), 10\% fetal bovine serum (FBS) (Hyclone Laboratories, Logan, Utah, USA), 100 units $/ \mathrm{mL}$ penicillin, $100 \mathrm{units} / \mathrm{mL}$ streptomycin and $0.25 \mu \mathrm{g} / \mathrm{mL}$ amphotericin B (Gibco, Life Technologies Corporation, Paisley, UK). One week prior to the assay, cells were placed in media containing 10\% dextran-charcoal treated FBS without antibiotic 
supplements. Cells were seeded at $5 \times 10^{4}$ cells per well in 96 -well luminometer plates (Corning Incorporated, New York, USA) and allowed to attach overnight. The dosing medium contained $5 \%$ dextran-charcoal treated FBS and the vehicle (ethanol) did not exceed $0.2 \%$. Each sample was tested alone in a four dilution series as well as in the presence of $0.1 \mathrm{nM} \mathrm{E}_{2}$ (to test for anti-estrogenic activity) or

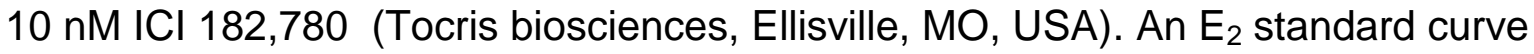
(ranging from $100 \mathrm{pM}$ to $0.1 \mathrm{pM}$ ), vehicle control (ethanol), antagonist control (100 pM E $E_{2}$ plus $10 \mathrm{nM} \mathrm{ICl} 182,780$ ) and background control (vehicle plus $10 \mathrm{nM} \mathrm{ICl}$ 182,780 ) were included on each plate. The exposed cells were incubated for $24 \mathrm{~h}$ (37 ${ }^{\circ} \mathrm{C}, 5 \% \mathrm{CO}_{2}$ ). After $24 \mathrm{~h}$ exposure, cells were washed with phosphate buffered saline (PBS) (Gibco, Life Technologies Corporation, Paisley, UK) and $25 \mu \mathrm{L}$ lysis buffer (Promega, Madison, Wisconsin, USA) was added to each well. The lysis buffer was activated by one freeze-thaw cycle. The assay plate was placed in a luminometer with two injectors (LUMIstar OPTIMA, BMG Labtech, Offenburg, Germany), programmed to add $25 \mu \mathrm{L}$ reaction buffer, followed by $25 \mu \mathrm{L} 1 \mathrm{mM}$ D-luciferin (Promega, Madison, Wisconsin, USA) to each well. Relative light unit readings were converted to a fold induction above the vehicle control. The $E_{2}$ standard curve was fitted (sigmoidal function, variable slope) using Graphpad Prism (version 4). EEq values of extracts with a greater than two-fold induction above the vehicle control were interpolated from the $E_{2}$ standard curve and corrected with the appropriate dilution factor for each sample. 


\subsection{Target chemical analyses}

Extracts were analysed for the following target chemicals using UPLC-MS/MS: BPA, NP, DEHA, dibutyl phthalate (DBP), di(2-ethylhexyl) phthalate (DEHP), diisononylphthalate (DINP), $E_{2}$, estrone $\left(E_{1}\right)$ and ethynylestradiol $\left(E_{2}\right)$.

Stock solutions of $10 \mathrm{mg} / \mathrm{mL}$ were prepared for all the standards. All standards were purchased from Sigma-Aldrich (St. Louis, MO, USA), except for the deuterated BPA (dBPA) internal standard which was from Cambridge Isotope Laboratories (Tewksbury, Massachusetts, USA). NP, BPA, dBPA (internal standard), $E_{2}$ and $E_{2}$ were prepared in methanol (Romil, Cambridge, UK), $\mathrm{E}_{1}$ in acetone (Sigma-Aldrich, St. Louis, MO, USA) and DEHA, DEHP and DBP in dichloromethane (DCM) (SigmaAldrich, St. Louis, MO, USA). A concentration range of stock solution was prepared in crimp vials ranging from $250 \mu \mathrm{g} / \mathrm{L}$ to $5 \mathrm{ng} / \mathrm{L}$ for $\mathrm{NP}, \mathrm{BPA}, \mathrm{E}_{1}, \mathrm{E}_{2}$ and $\mathrm{EE}_{2}$ and from $1 \mathrm{mg} / \mathrm{L}$ to $100 \mu \mathrm{g} / \mathrm{L}$ for DEHA, DEHP and DBP. For each concentration, $1 \mathrm{~mL}$ was transferred to a new vial and evaporated under a stream of nitrogen at $40^{\circ} \mathrm{C}$. The dried extract samples and standards (except for the DEHA and phthalate standards) were resuspended in $100 \mu \mathrm{L} 1 \mathrm{M}$ sodium carbonate $\left(\mathrm{Na}_{2} \mathrm{CO}_{3}\right)$ (Merck, Darmstadt, Germany). A 2 mg/L solution of dansyl chloride (Sigma-Aldrich, St. Louis, MO, USA) was prepared in acetone and $100 \mu \mathrm{L}$ was added to each vial. The vials were capped and vortexed and derivatized for 2 minutes at $60^{\circ} \mathrm{C}$ and analysed using UPLCMS/MS. The DEHA and phthalate standards were resuspended in $200 \mu \mathrm{L}$ acetonitrile (Romil, Cambridge, UK) and were injected without further preparation. The detection limit (dl) and level of quantification (loq) obtained for the target chemicals were $0.5 \mathrm{ng} / \mathrm{L}(\mathrm{dl})$ and $5 \mathrm{ng} / \mathrm{L}$ (loq) for BPA, NP, $\mathrm{E}_{2}$ and $\mathrm{EE}_{2}, 800 \mathrm{ng} / \mathrm{L}$ (dl) and $1000 \mathrm{ng} / \mathrm{L}$ (loq) for DEHA and DINP, $10000 \mathrm{ng} / \mathrm{L}$ (dl) and $40000 \mathrm{ng} / \mathrm{L}$ (loq) for 
DBP and DEHP and $5 \mathrm{ng} / \mathrm{L}(\mathrm{dl})$ and $10 \mathrm{ng} / \mathrm{L}(\mathrm{loq})$ for $\mathrm{E}_{1}$. In order to determine the recoveries of the target chemicals after the extraction process, triplicate $1 \mathrm{LddH}_{2} \mathrm{O}$ samples were spiked with a standard cocktail containing all the target chemicals. The final concentration of each target chemical was $200 \mathrm{ng} / \mathrm{L}$. The spiked and unspiked (control) samples were extracted and analysed for the target chemicals. Recoveries obtained for this method were $104 \%$ for BPA; $64 \%$ for NP; $163 \%$ for DEHA; $167 \%$ for DBP; $102 \%$ for DEHP; $88 \%$ for $E_{2} ; 84 \%$ for $E_{1}$ and $89 \%$ for $E_{2}$. The instrument and method details for UPLC-MS/MS analyses are available in the supplementary information (see A.1).

\subsection{Human health risk assessment}

A Human Health Risk Assessment was conducted to assess the potential human health impacts of the chemicals found in the tested water samples. The assessment followed the methodology described by Genthe et al. (2010). The health risk assessment was based on adult exposure excluding children and vulnerable populations. The following exposure parameter values were used for the risk calculations: 350 events per year; body weight of $70 \mathrm{~kg}$; lifetime of 70 years; consumption of $2 \mathrm{~L}$ water per day and chronic exposure duration of 30 years.

Bioassay results were compared to the trigger value of $0.7 \mathrm{ng} / \mathrm{L}$ for estrogenic activity in drinking water suggested by Genthe et al. (2010). If the trigger value is exceeded, possible adverse health effects are implicated and necessitate further investigation and testing of the water. 
The concentrations of the identified target chemicals were used to calculate the total dose a person may be exposed to. The computer programme Risk*Assistant was used for the calculations of potential exposure concentrations. The following calculation was used to determine human exposure to the identified substances on a daily basis:

$\mathrm{ADD}=\left(\mathrm{C}_{\text {medium }} \times \mathrm{IR}\right) / \mathrm{BW}$

where:

ADD is the average daily dose $(\mathrm{mg} / \mathrm{kg} /$ day $)$

$\mathrm{C}_{\text {medium }}$ is the concentration of the substance in the water $(\mathrm{mg} / \mathrm{kg})$

$\mathrm{IR}$ is the ingestion rate (L/day)

BW is the body weight $(\mathrm{kg})$

For toxic chemicals a hazard quotient $(\mathrm{HQ})$ was calculated using the following formula:

$H Q=A D D / R f D$

where:

RfD is the reference dose reported by the USEPA (USEPA, 2011)

A HQ less than 1 is considered to be safe for a lifetime exposure

For carcinogenic chemicals for exposures that last less than a lifetime, the lifetime average daily dose (LADD) was calculated as: 
$\mathrm{LADD}=\mathrm{ADD} \times \mathrm{ED} / \mathrm{Lft}$

where:

ED is the exposure duration (years)

Lft is lifetime (years)

The excess cancer risk was calculated as a function of oral potency factor $(\beta)$ as reported by the USEPA (USEPA, 2011) and dose:

Risk $=\beta \times$ LADD

The WHO acceptable risk level is $10^{-5}$, meaning that the excess risk of developing cancer is deemed acceptable if ingestion of the substance results in one additional cancer case per hundred thousand of the population or less.

\section{Results and discussion}

\subsection{Bioassays for estrogenic activity}

None of the water extracts from the distribution points were above the detection limit in the YES bioassay. Although the YES bioassay has several advantages, including its robustness, lack of endogenous receptors that can interfere with the response of the cells, lower cost and uncomplicated bioassay procedure, yeast-based bioassays are less sensitive compared to human cell lines (Connolly et al., 2011; Kunz et al., 2015). Estrogenic activity was also below the detection limit in drinking water from Brazil (Bergamasco et al., 2011) and Finland (Omoruyi and Pohjanvirta, 2015) using 
yeast based assays. The YES bioassay is therefore not as suitable for detection of low levels of estrogenic activity normally found in drinking water.

Estrogenic activity was detected in distribution point water using the T47D-KBluc bioassay, with EEq values ranging from 0.002 to $0.114 \mathrm{ng} / \mathrm{L}$. The EEq values for each distribution point is summarized in Table 2. None of the samples showed antiestrogenic activity. Estrogenic activity was also detected in drinking water from Italy (Maggioni et al., 2013), Taiwan (Gou et al., 2016), The Netherlands (Brand et al., 2013) and the US (Stanford et al., 2010) using mammalian cell line assays, with EEq values ranging from below the level of quantification to $1.3 \mathrm{ng} / \mathrm{L}$ (Table 4).

\subsection{Target chemical analyses}

BPA, DEHA, DBP, DEHP, DINP, $E_{2}$ and $E_{1}$ were detected in distribution point water extracts from Pretoria and Cape Town. $\mathrm{EE}_{2}$ was only detected at one distribution point in Pretoria (PTA08) in all four sampling periods. None of the Cape Town samples had $\mathrm{EE}_{2}$ concentrations above the dl. NP was below the detection limit in all the extracts. The results of the target chemical analysis are summarized in Table 3 (the individual results for each sampling period is available in the supplementary information, see A.2). The presence of EDCs in drinking water could possibly be ascribed to either, the contamination of the source water and ineffective water treatment methodologies or, in the case of the plasticizers, migration from reservoir linings or plastic pipes at water distribution systems. 
Table 2: Estradiol equivalent (EEq) concentrations ( $\mathrm{ng} / \mathrm{L})$ in distribution point water from Pretoria (PTA) and Cape Town (CPT), South Africa, using the T47D-KBluc bioassay

\begin{tabular}{|c|c|c|c|c|}
\hline Site & Oct 2013 & Jan 2014 & Apr 2014 & Jul 2014 \\
\hline PTA01 & $0.089 \pm 0.006$ & $0.015 \pm 0.003$ & $0.074 \pm 0.003$ & $0.058 \pm 0.006$ \\
\hline PTA02 & $<\mathrm{dl}$ & $<\mathrm{dl}$ & $<\mathrm{dl}$ & $0.023 \pm 0.005$ \\
\hline PTA03 & $0.061 \pm 0.009$ & $<\mathrm{dl}$ & $<\mathrm{dl}$ & $0.077 \pm 0.031$ \\
\hline PTA04 & $<\mathrm{dl}$ & $<\mathrm{dl}$ & $<\mathrm{dl}$ & $<\mathrm{dl}$ \\
\hline PTA05 & $<\mathrm{dl}$ & $<\mathrm{dl}$ & $<\mathrm{dl}$ & $0.024 \pm 0.006$ \\
\hline PTA06 & $0.032 \pm 0.004$ & $0.015 \pm 0.005$ & $<\mathrm{dl}$ & $0.077 \pm 0.025$ \\
\hline PTA07 & $<\mathrm{dl}$ & $<\mathrm{dl}$ & $<\mathrm{dl}$ & $<\mathrm{dl}$ \\
\hline PTA08 & $<\mathrm{dl}$ & $<\mathrm{dl}$ & $<\mathrm{dl}$ & $<\mathrm{dl}$ \\
\hline PTA09 & $0.013 \pm 0.001$ & $<\mathrm{dl}$ & $<\mathrm{dl}$ & $<\mathrm{dl}$ \\
\hline PTA10 & $<\mathrm{dl}$ & $<\mathrm{dl}$ & $<\mathrm{dl}$ & $<\mathrm{dl}$ \\
\hline Site & Oct 2013 & Jan 2014 & Apr 2014 & Jul 2014 \\
\hline СРТ01 & $<\mathrm{dl}$ & $<\mathrm{dl}$ & $<\mathrm{dl}$ & $<\mathrm{dl}$ \\
\hline СРТ02 & $<\mathrm{dl}$ & $<\mathrm{dl}$ & $<\mathrm{dl}$ & $<\mathrm{dl}$ \\
\hline СРТ03 & $<\mathrm{dl}$ & $<\mathrm{dl}$ & $<\mathrm{dl}$ & $<\mathrm{dl}$ \\
\hline СРТ04 & $0.004 \pm 0.0003$ & $0.004 \pm 0.001$ & $0.003 \pm 0.0003$ & $0.005 \pm 0.001$ \\
\hline СРТ05 & $0.002 \pm 0.001$ & $<\mathrm{dl}$ & $<\mathrm{dl}$ & $0.003 \pm 0.001$ \\
\hline СРT06 & $0.004 \pm 0.001$ & $0.003 \pm 0.0003$ & $0.004 \pm 0.0004$ & $0.002 \pm 0.0004$ \\
\hline СРТ07 & $0.004 \pm 0.001$ & $<\mathrm{dl}$ & $0.003 \pm 0.001$ & $0.041 \pm 0.014$ \\
\hline СРТ08 & $0.006 \pm 0.001$ & $0.005 \pm 0.002$ & $0.004 \pm 0.001$ & $0.026 \pm 0.004$ \\
\hline СРТ09 & $<\mathrm{dl}$ & $<\mathrm{dl}$ & $0.044 \pm 0.015$ & $0.020 \pm 0.001$ \\
\hline CPT10 & $0.005 \pm 0.001$ & $<\mathrm{dl}$ & $<\mathrm{dl}$ & $0.114 \pm 0.044$ \\
\hline
\end{tabular}

$<\mathrm{dl}$ : below detection limit of the assay 
Table 3: Target chemical concentrations (ng/L) in distribution point water from Pretoria (PTA) and Cape Town (CPT), South Africa, using UPLC-MS/MS

\begin{tabular}{|c|c|c|c|c|c|c|c|c|c|}
\hline Site $^{a}$ & BPA & NP & DEHA & DBP & DEHP & DINP & $E_{2}$ & $E_{1}$ & $\mathrm{EE}_{2}$ \\
\hline PTA01 & 0.44 & $<\mathrm{dl}$ & 2.66 & 214.11 & 78.17 & 38.49 & $<\mathrm{dl}$ & $<\mathrm{dl}$ & $<\mathrm{dl}$ \\
\hline PTA02 & 0.67 & $<\mathrm{dl}$ & 2.67 & 272.14 & 155.71 & 106.31 & 0.03 & 2.32 & $<\mathrm{dl}$ \\
\hline PTA03 & 3.79 & $<\mathrm{dl}$ & 3.19 & 319.36 & 81.99 & 26.05 & $<\mathrm{dl}$ & 3.41 & $<\mathrm{dl}$ \\
\hline PTA04 & 2.63 & $<\mathrm{dl}$ & 2.62 & 240.51 & 119.65 & 28.56 & $<\mathrm{dl}$ & $<\mathrm{dl}$ & $<\mathrm{dl}$ \\
\hline PTA05 & 2.66 & $<\mathrm{dl}$ & 1.97 & 260.45 & 99.04 & 8.34 & $<\mathrm{dl}$ & $<\mathrm{dl}$ & $<\mathrm{dl}$ \\
\hline PTA06 & 0.85 & $<\mathrm{dl}$ & 3.71 & 300.97 & 93.27 & 59.84 & $<\mathrm{dl}$ & 3.61 & $<\mathrm{dl}$ \\
\hline PTA07 & 0.42 & $<\mathrm{dl}$ & 3.20 & 176.15 & 147.98 & 105.38 & $<\mathrm{dl}$ & $<\mathrm{dl}$ & $<\mathrm{dl}$ \\
\hline PTA08 & 1.08 & $<\mathrm{dl}$ & 2.27 & 248.01 & 60.71 & 30.51 & $<\mathrm{dl}$ & $<\mathrm{dl}$ & 0.02 \\
\hline PTA09 & 0.35 & $<\mathrm{dl}$ & 2.68 & 283.28 & 124.94 & 15.96 & $<\mathrm{dl}$ & $<\mathrm{dl}$ & $<\mathrm{dl}$ \\
\hline PTA10 & 0.25 & $<\mathrm{dl}$ & 2.64 & 336.31 & 238.07 & 54.74 & $<\mathrm{dl}$ & $<\mathrm{dl}$ & $<\mathrm{dl}$ \\
\hline Median & 0.39 & $<$ dl & 2.85 & 260.18 & 78.09 & 37.50 & 0.03 & 2.87 & 0.02 \\
\hline СРТ01 & 0.17 & $<\mathrm{dl}$ & 3.93 & 629.09 & 165.99 & 350.09 & $<\mathrm{dl}$ & $<\mathrm{dl}$ & $<\mathrm{dl}$ \\
\hline СРТ02 & 0.17 & $<\mathrm{dl}$ & 2.65 & 418.73 & 60.78 & 61.86 & 0.02 & 0.36 & $<\mathrm{dl}$ \\
\hline СРТ03 & 1.99 & $<\mathrm{dl}$ & 2.54 & 366.40 & 104.63 & 194.91 & 0.04 & $<\mathrm{dl}$ & $<\mathrm{dl}$ \\
\hline СРT04 & 1.03 & $<\mathrm{dl}$ & 2.84 & 383.46 & 3415.19 & 50.75 & $<\mathrm{dl}$ & $<\mathrm{dl}$ & $<\mathrm{dl}$ \\
\hline СРТ05 & 7.43 & $<\mathrm{dl}$ & 3.46 & 618.66 & 256.44 & 330.81 & $<\mathrm{dl}$ & $<\mathrm{dl}$ & $<\mathrm{dl}$ \\
\hline СРТ06 & 0.26 & $<\mathrm{dl}$ & 3.43 & 287.90 & 186.13 & 65.75 & 0.05 & $<\mathrm{dl}$ & $<\mathrm{dl}$ \\
\hline СРТ07 & 0.58 & $<\mathrm{dl}$ & 3.26 & 231.02 & 74.24 & 79.52 & 0.04 & $<\mathrm{dl}$ & $<\mathrm{dl}$ \\
\hline СРТ08 & 0.41 & $<\mathrm{dl}$ & 3.77 & 318.71 & 95.69 & 52.59 & $<\mathrm{dl}$ & $<\mathrm{dl}$ & $<\mathrm{dl}$ \\
\hline СРТ09 & 1.76 & $<\mathrm{dl}$ & 3.40 & 480.23 & 360.36 & 44.75 & $<\mathrm{dl}$ & 1.14 & $<\mathrm{dl}$ \\
\hline CPT10 & 0.61 & $<\mathrm{dl}$ & 4.07 & 536.16 & 127.10 & 250.26 & $<\mathrm{dl}$ & $<\mathrm{dl}$ & $<\mathrm{dl}$ \\
\hline Median & 0.26 & $<$ dl & 3.38 & 342.62 & 103.25 & 54.81 & 0.04 & 0.75 & $<$ dl \\
\hline
\end{tabular}

${ }^{a}$ The table present average concentrations over four sampling periods; <dl: below detection limit.

Values were adjusted for the $1000 \times$ concentration of the samples during SPE 
BPA concentrations ranged from 0.01 to $28.83 \mathrm{ng} / \mathrm{L}$ and were detected in $90 \%$ of the Pretoria and $93 \%$ of the Cape Town samples. NP was below the detection limit in this study. Drinking water might contain residual amounts of chlorine from the disinfection procedure that reacts with NP to form diverse chlorinated byproducts ( $\mathrm{Hu}$ et al., 2002). This could explain why NP was not detected in the samples from this project. DEHA was detected in all the samples, with concentrations ranging from 1.07 to $4.97 \mathrm{ng} / \mathrm{L}$. DBP was detected in $88 \%$ of the Pretoria samples and in all Cape Town samples. DBP concentrations ranged from 109.48 to $1065.14 \mathrm{ng} / \mathrm{L}$, but the median concentration was $260.18 \mathrm{ng} / \mathrm{L}$ in Pretoria and $342.62 \mathrm{ng} / \mathrm{L}$ in Cape Town samples. DEHP was detected in 65\% Pretoria and $83 \%$ Cape Town samples and ranged from 40.20 to $5150.76 \mathrm{ng} / \mathrm{L}$, with median concentrations of $78.09 \mathrm{ng} / \mathrm{L}$ for Pretoria and $103.25 \mathrm{ng} / \mathrm{L}$ for Cape Town samples. DINP were detected in $70 \%$ samples from Pretoria and $85 \%$ samples from Cape Town. The concentrations ranged from 3.02 to $1250.75 \mathrm{ng} / \mathrm{L}$, with a median concentration of $37.50 \mathrm{ng} / \mathrm{L}$ for Pretoria and $54.81 \mathrm{ng} / \mathrm{L}$ for Cape Town samples.

$E_{2}$ was detected in 2.5\% Pretoria and 10\% Cape Town samples, with concentrations ranging from 0.02 to $0.04 \mathrm{ng} / \mathrm{L}$. $\mathrm{E}_{1}$ was detected in $10 \%$ Pretoria and $5 \%$ Cape Town samples and concentrations ranged from 0.36 to $4.89 \mathrm{ng} / \mathrm{L}$. $\mathrm{EE}_{2}$ was detected in $10 \%$ of the Pretoria samples and the concentrations ranged from 0.003 to $0.06 \mathrm{ng} / \mathrm{L}$. In this study, $E_{1}$ concentrations were at least twenty times higher than the $E_{2}$ concentrations. Compared to other estrogens, $E_{1}$ is excreted by humans and livestock at relatively high concentrations (Wise et al., 2011). Furthermore, $E_{2}$ is biodegradable to $E_{1}$ in surface waters (Jurgens et al., 2002) and during sewage 
treatment plant processes (Ternes et al., 1999a), rendering $E_{1}$ one of the most frequently detected estrogens (Burkhardt-Holm, 2010).

More advanced treatment systems might be more effective at removing EDCs from drinking water, however, it is not always a viable option due to much higher operating costs (Racz and Goel, 2010). Strategies to limit source contamination and effectively remove EDCs from source water are also recommended and may include the development of more effective water treatment technologies and public awareness campaigns (e.g. to reduce the use of and recycle plastic products and to dispose of unused pharmaceuticals in a responsible manner).

When comparing the chemical and bioassay results, EEq values were much lower than expected. For example, for PTA03 in October 2013 the $E_{1}$ concentration was $3.41 \mathrm{ng} / \mathrm{L}$. Taking into account the relative potency of $E_{1}$ in the T47D-KBluc assay (0.46), an EEq of at least $1.57 \mathrm{ng} / \mathrm{L}$ was expected. However, the EEq for this sample was only $0.016 \mathrm{ng} / \mathrm{L}$. The results indicate that antagonists might be present in the water samples. On the other hand, estrogenic activity was detected in some of the samples that were below the detection limit for the estrogens $E_{1}, E_{2}$ and $E_{2}$. As the concentrations of BPA were below the concentrations expected to react in the bioassays, other chemicals or pharmaceuticals with estrogenic activity might be present in those samples. A broad chemical screening is therefore recommended to identify other chemicals/pharmaceuticals that may be present in the water samples.

Table 4 presents a comparison of the estrogenic activity and levels of the target chemicals in this study to the activity and concentrations found in drinking water from 
other countries. From the table, it is clear that BPA, NP, DEHA, phthalates and natural and synthetic estrogens are present in drinking water worldwide at a wide range of concentrations. Very few studies assessed drinking water for DINP, but this phthalate was detected in drinking water from this study as well as in drinking water from eastern China (Shi et al., 2012). It is therefore recommended to include DINP when screening environmental or drinking water samples for phthalates.

\subsection{Human health risk assessment}

When analysing water samples using bioassays, trigger values are useful to judge whether further investigation is needed. Exceeding the trigger value does not necessarily mean that a health effect is expected, but further investigation is needed to identify substances responsible for the activity and could ultimately lead to a full risk assessment (Brand et al., 2013). In this study, none of the samples were above the $0.7 \mathrm{ng} / \mathrm{L}$ trigger value for estrogenic activity in drinking water proposed by Genthe et al. (2010).

For the health risk assessment $95^{\text {th }}$ percentiles were used as 'reasonable maximum' values to determine the risks associated with the consumption of distribution point water. The health risk assessment is summarised in Table 5. Using reasonable maximum values, the $\mathrm{HQ}$ for $\mathrm{E}_{1}$ in Pretoria distribution point samples were above 1 , indicating potential health risk. In contrast, the HQ based on EEq values from the T47D-KBluc assay were below 1 for the Pretoria distribution point samples, indicating acceptable health risks. This might indicate the presence of substances with antagonistic effects in the water samples. Chemical screening assays are 
Table 4: Comparison of target chemicals in drinking water from various countries

\begin{tabular}{|c|c|c|c|c|c|c|c|c|c|c|c|}
\hline Country & $\begin{array}{l}\text { BPA } \\
\text { (ng/L) }\end{array}$ & $\begin{array}{l}\text { NP } \\
\text { (ng/L) }\end{array}$ & $\begin{array}{l}\text { DEHA } \\
\text { (ng/L) }\end{array}$ & $\begin{array}{l}\mathrm{DBP} \\
\text { (ng/L) }\end{array}$ & $\begin{array}{l}\text { DEHP } \\
\text { (ng/L) }\end{array}$ & $\begin{array}{l}\text { DINP } \\
\text { (ng/L) }\end{array}$ & $\begin{array}{l}E_{2} \\
\text { (ng/L) }\end{array}$ & $\begin{array}{l}E_{1} \\
\text { (ng/L) }\end{array}$ & $\begin{array}{l}\mathrm{EE}_{2} \\
\text { (ng/L) }\end{array}$ & $\begin{array}{l}\mathrm{EEq} \\
\text { (ng/L) }\end{array}$ & Reference \\
\hline $\begin{array}{l}\text { Pretoria and Cape Town, } \\
\text { South Africa }\end{array}$ & $0.01-28.83$ & $<\mathrm{dl}$ & $0.91-4.97$ & $\begin{array}{l}109- \\
1065\end{array}$ & $39-5150$ & 3-1 251 & $0.02-0.05$ & $0.36-4.89$ & $0.003-0.06$ & $0.002-0.144^{d}$ & This study \\
\hline Brazil (Campinas) & $160^{\mathrm{b}}$ & $<\mathrm{dl}$ & - & - & - & - & $<l o q$ & $<l o q$ & $<\mathrm{dl}$ & - & (Sodré et al., 2010) \\
\hline Brazil (São Paulo) & $<\mathrm{dl}$ & - & - & - & - & - & $<\mathrm{dl}$ & $<\mathrm{dl}$ & $<\mathrm{dl}$ & $<\mathrm{dl}^{\mathrm{e}}$ & (Bergamasco et al., 2011) \\
\hline Brazil (Piracicaba city) & - & - & - & - & - & - & $<\mathrm{dl}$ & $<\mathrm{dl}$ & $<\mathrm{dl}$ & - & (Torres et al., 2015) \\
\hline Canada (Ontario) & - & - & - & - & - & - & - & $0.03-1.5$ & - & - & (Metcalfe et al., 2014) \\
\hline China (Chongqing) & - & $100-2700$ & - & - & - & - & - & - & - & - & (Shao et al., 2005) \\
\hline China & - & - & $<\mathrm{dl}-25^{\mathrm{b}}$ & $1.1-930^{b}$ & $6.2-280^{b}$ & $<\mathrm{dl}-29^{\mathrm{b}}$ & - & - & - & - & (Shi et al., 2012) \\
\hline China & $10.8^{\mathrm{a}} ; 128^{\mathrm{c}}$ & $27^{\mathrm{a}} ; 558^{\mathrm{c}}$ & - & - & - & - & $0.04^{\mathrm{a}} ; 0.1^{\mathrm{c}}$ & $0.3^{\mathrm{a}} ; 1.7^{\mathrm{c}}$ & - & - & (Fan et al., 2013) \\
\hline China & - & - & - & $180^{\mathrm{a}} ; 350^{\mathrm{b}}$ & $180^{\mathrm{a}} ; 770^{\mathrm{b}}$ & - & - & - & - & - & (Liu et al., 2015) \\
\hline China (Jiangsu province) & $0.17-1.22$ & $<\mathrm{dl}$ & - & - & - & - & - & - & - & $0.02-0.20^{\mathrm{e}}$ & (Lv et al., 2016) \\
\hline Finland & - & - & - & - & - & - & - & - & - & $<\mathrm{dl}^{\mathrm{e}}$ & (Omoruyi and Pohjanvirta, 2015) \\
\hline France (Paris) & - & - & - & - & - & - & - & - & - & $<\mathrm{dll}^{\dagger}$ & (Jugan et al., 2009) \\
\hline France & $<9-50$ & $<35-505$ & - & - & - & - & - & - & - & - & (Colin et al., 2014) \\
\hline Germany & $0.50-2.0$ & $2.50-16$ & - & - & - & - & $0.20-2.1$ & $0.20-0.60$ & $0.15-0.50$ & - & (Kuch and Ballschmiter, 2001) \\
\hline Germany (Leipzig) & - & - & - & 380 & 50 & - & - & - & - & - & (Luks-Betlej et al., 2001) \\
\hline Italy & $<\mathrm{dl}$ & $<\mathrm{dl}$ & - & - & - & - & $<\mathrm{dl}$ & $<\mathrm{dl}$ & $<\mathrm{dl}$ & - & (Loos et al., 2007) \\
\hline Italy & $0.82-102$ & $10.30-84.00$ & - & - & - & - & $<\mathrm{dl}$ & $<\mathrm{dl}$ & $<\mathrm{dl}$ & $0.0136^{\mathrm{c}, \mathrm{g}}$ & (Maggioni et al., 2013) \\
\hline
\end{tabular}




\begin{tabular}{|c|c|c|c|c|c|c|c|c|c|c|c|}
\hline Poland & - & - & - & 640 & 60 & - & - & - & - & - & (Luks-Betlej et al., 2001) \\
\hline Portugal (Lisbon) & - & - & 90 & 520 & 60 & - & - & - & - & - & (Serodio and Nogueira, 2006) \\
\hline Portugal & - & - & - & $<\mathrm{dl}$ & $130-190$ & - & - & - & - & - & (Santana et al., 2014) \\
\hline Portugal & $<\mathrm{dl}$ & $<l o q$ & - & - & - & - & $<\mathrm{dl}$ & $<\mathrm{dl}$ & $<\mathrm{dl}$ & - & (Carvalho et al., 2015) \\
\hline Spain (Catalonia) & $6-25$ & 24 & - & $16-32$ & 331 & - & - & - & - & - & (Casajuana and Lacorte, 2003) \\
\hline Spain (Madrid) & - & - & - & $633 \pm 255$ & $<\mathrm{dl}$ & - & - & - & - & - & $\begin{array}{l}\text { (Dominguez-Morueco et al., } \\
\text { 2014) }\end{array}$ \\
\hline Spain (Madrid) & $3.7-50.3$ & $2.5-20.5$ & - & - & - & - & $<\mathrm{dl}$ & $<\mathrm{dl}$ & $<\mathrm{dl}$ & - & (Esteban et al., 2014) \\
\hline Taiwan & $<\mathrm{dl}$ & $<\mathrm{dl}$ & - & $163-210^{b}$ & $773-1350^{b}$ & $<\mathrm{dl}$ & - & - & - & $<\mathrm{dl}-1.3^{\mathrm{d}}$ & (Gou et al., 2016) \\
\hline The Netherlands & - & - & - & - & - & - & - & - & - & $0.022-0.032^{h}$ & (Brand et al., 2013) \\
\hline $\begin{array}{l}\text { US (Cape Cod, } \\
\text { Massachusetts) }\end{array}$ & $20-44$ & $<\mathrm{dl}$ & - & - & - & - & - & - & - & - & (Rudel et al., 1998) \\
\hline US & $420^{c}$ & $<\mathrm{dl}$ & - & - & - & - & - & - & - & - & (Stackelberg et al., 2004) \\
\hline US & 25 & $97^{a}$ & - & - & $<\mathrm{dl}$ & - & $<\mathrm{dl}$ & $<\mathrm{dl}$ & $<\mathrm{dl}$ & - & (Benotti et al., 2009) \\
\hline US & - & - & - & - & - & - & - & - & - & $0.19-0.77^{i}$ & (Stanford et al., 2010) \\
\hline US (Southeastern) & $0-44.3$ & $12.4-60.6$ & - & - & - & - & - & - & - & - & (Padhye et al., 2014) \\
\hline US & - & - & - & - & - & - & $<\mathrm{dl}$ & $<\mathrm{dl}$ & $<\mathrm{dl}$ & - & (Conley et al., 2016) \\
\hline
\end{tabular}

${ }^{\text {a: }}$ Median concentration; ${ }^{\text {b}}$ : Mean concentration; $\quad$ c: Maximum concentration; ${ }^{\mathrm{d}}$ : T47D-KBluc bioassay; ${ }^{\mathrm{e}}$ : yeast-based bioassay; f: luciferase reporter gene assay using MELN cells; ${ }^{\mathrm{g}}$ : HELN-ER $\alpha$ luciferase reporter assay; ${ }^{\text {h: }}$ ER $\alpha$ CALUC; $:$ E-screen; -: not analysed; <dl: below detection limit; <loq: below level of quantification 
therefore recommended to try and identify possible chemicals or pharmaceuticals in the water with antagonistic activity.

Although the $H Q$ for $E_{1}$ was above 1 in the Pretoria distribution point samples, $E_{1}$ was only detected in four samples and in three different sampling points, indicating that consumers are not continuously exposed to $E_{1}$ in their drinking water. It is therefore a more realistic scenario to calculate the $\mathrm{HQ}$ using the average concentration. If the $\mathrm{HQ}$ is recalculated using the average concentration, the $\mathrm{HQ}$ is 0.21 , indicating acceptable health risks associated with $E_{1}$ in Pretoria distribution point water. A monitoring strategy is however advised, to provide a more accurate assessment of the frequency of $E_{1}$ detections in drinking water, for a more accurate health risk assessment. For all other distribution points the $\mathrm{HQ}$ was below one for all the target chemicals and is therefore considered safe for a lifetime exposure. The carcinogenic risks for DEHP and DEHA were also below $10^{5}$, and therefore deemed acceptable.

Overall, this study indicated acceptable human health and carcinogenic risks associated with exposure to BPA, phthalates and estrogenic compounds through the consumption of distribution point water. EDCs in drinking water were also below the levels expected to have adverse health effects in Spain (Dominguez-Morueco et al., 2014), China (Liu et al., 2015) and Portugal (Santana et al., 2014). Although this study indicated an acceptable human health and carcinogenic risk associated with the consumption of the distribution point water, it should be kept in mind that this study only focussed on selected target chemicals. Other hazardous chemicals, not 
Table 5: Health risk assessment of distribution point water in Pretoria and Cape Town

\begin{tabular}{|c|c|c|c|c|c|c|c|c|c|}
\hline $\begin{array}{l}\text { Target } \\
\text { Chemical }\end{array}$ & $\begin{array}{l}\text { Water } \\
\text { source }\end{array}$ & $\begin{array}{l}\text { Concentration } \\
\text { (95th percentile } \\
\text { in } \mathrm{ng} / \mathrm{L})\end{array}$ & $\begin{array}{l}\text { ADD } \\
(\mathrm{mg} / \mathrm{kg} / \mathrm{d})\end{array}$ & $\begin{array}{l}\text { LADD } \\
(\mathrm{mg} / \mathrm{kg} / \mathrm{d})\end{array}$ & $\begin{array}{l}\text { RfD } \\
(\mathrm{mg} / \mathrm{kg} / \mathrm{d})\end{array}$ & $\begin{array}{l}\text { Trigger } \\
\text { value } \\
\text { (ng/L) }^{\mathrm{a}}\end{array}$ & $\begin{array}{l}\text { Hazard } \\
\text { Quotient }\end{array}$ & Slope & Risk \\
\hline \multirow[t]{2}{*}{ BPA } & PTA & 5.84 & 1.67E-07 & 7.15E-08 & $0.05^{\mathrm{b}}$ & & 0.000003 & & \\
\hline & CPT & 2.42 & 6.91E-08 & 2.96E-08 & 0.05 & & 0.000001 & & \\
\hline \multirow[t]{2}{*}{ DEHA } & PTA & 3.95 & 1.13E-07 & 4.84E-08 & $0.6^{c}$ & & $2 \mathrm{E}-07$ & 0.0012 & $5.81 \mathrm{E}-11$ \\
\hline & CPT & 4.71 & 1.35E-07 & $5.77 \mathrm{E}-08$ & 0.6 & & $2 \mathrm{E}-07$ & 0.0012 & $6.92 \mathrm{E}-11$ \\
\hline \multirow[t]{2}{*}{ DBP } & PTA & 391.29 & $1.12 \mathrm{E}-05$ & 4.79E-06 & $0.1^{d}$ & & 0.00011 & & \\
\hline & CPT & 954.88 & 2.73E-05 & 1.17E-05 & 0.1 & & 0.00027 & & \\
\hline \multirow[t]{2}{*}{ DEHP } & PTA & 251.42 & 7.18E-06 & $3.08 \mathrm{E}-06$ & $0.02^{\mathrm{e}}$ & & 0.00036 & 0.014 & 4.31E-08 \\
\hline & CPT & 4127.59 & $1.18 \mathrm{E}-04$ & 5.05E-05 & 0.02 & & 0.0059 & 0.014 & 7.08E-07 \\
\hline \multirow[t]{2}{*}{ DINP } & PTA & 118.99 & $3.40 \mathrm{E}-06$ & $1.46 \mathrm{E}-06$ & $0.115^{\dagger}$ & & 0.00003 & & \\
\hline & СРT & 770.95 & $2.20 \mathrm{E}-05$ & $9.44 \mathrm{E}-06$ & 0.115 & & 0.00019 & & \\
\hline \multirow[t]{2}{*}{$E_{2}$} & PTA $^{9}$ & 0.03 & $8.57 \mathrm{E}-10$ & $3.67 \mathrm{E}-10$ & & 0.7 & 0.04 & & \\
\hline & СРT & 0.04 & $1.14 \mathrm{E}-09$ & $4.90 \mathrm{E}-10$ & & 0.7 & 0.06 & & \\
\hline \multirow[t]{2}{*}{$E_{1}$} & PTA & 2.38 & $6.80 \mathrm{E}-08$ & $2.91 \mathrm{E}-08$ & & 1.5 & 1.56 & & \\
\hline & CPT & 0.02 & $5.71 \mathrm{E}-10$ & $2.45 \mathrm{E}-10$ & & 1.5 & 0.01 & & \\
\hline \multirow[t]{2}{*}{$\mathrm{EE}_{2}$} & PTA & 0.01 & $2.86 \mathrm{E}-10$ & $1.22 \mathrm{E}-10$ & & 0.6 & 0.02 & & \\
\hline & CPT & $<\mathrm{dl}$ & & & & 0.6 & - & & \\
\hline \multirow[t]{2}{*}{ EEq } & PTA & 0.08 & & & & 0.7 & 0.11 & & \\
\hline & CPT & 0.04 & & & & 0.7 & 0.06 & & \\
\hline
\end{tabular}


tested for in this study, might also be present in the water samples and would add to the potential health risk. Furthermore, this study only focussed on estrogenic activity and selected target chemicals and did not account for other EDC activities, e.g. androgenic activity, anti-androgenic activity, thyroid activity, etc. This study was conducted in two of the larger, well-functioning municipalities in South Africa, but should also be extended to other municipalities in the country, where the EDC status of drinking water might be different. This is especially the case in municipalities where the water quality might not be of as high a quality as indicated by Blue Drop status (a certification programme indicating compliance of municipalities to drinking water quality requirements, available from http://www.dwa.gov.za/dir_ws/DWQR/default.asp).

\section{Conclusions}

Due to their ubiquity in the environment and endocrine disruptive activity, the potential impact of EDCs on public health is a reason for concern. This study revealed the presence of BPA, phthalates, DEHA and estrogenic hormones in distribution point water from Pretoria and Cape Town, South Africa. The estrogenic activity and levels of target chemicals were comparable to the levels found in other countries.

The presence of EDCs in drinking water can be ascribed to the contamination of the source water and ineffective water treatment methodologies or migration from reservoir linings or plastic pipes at water distribution systems. $E_{1}$ in Pretoria distribution point samples posed the highest potential health risk, but overall this 
study indicated acceptable human health and carcinogenic risks associated with the consumption of distribution point water from Pretoria and Cape Town.

Due to the fact that EDCs were frequently detected in Pretoria and Cape Town distribution point water, a monitoring strategy is recommended that can act as an early warning system. Other municipalities should also be assessed and assays for androgenic and thyroid activity should be included. Strategies to limit source contamination and effectively remove EDCs from source water are also recommended.

\section{Conflict of interest:}

The authors declare no conflict of interest.

\section{Acknowledgements:}

Funding: This work was supported by the South African Medical Research Council. The authors would also like to thank the staff from Scientific Services, City of Tshwane and Scientific Services, Cape Town Municipality for their assistance in selecting appropriate sampling sites and collecting water samples from the distribution points.

\section{References}

Benotti, M. J., Trenholm, R. A., Vanderford, B. J. , Holady, J. C. , Stanford, B. D., Snyder, S. A., 2009. Pharmaceuticals and endocrine disrupting compounds in U.S. drinking water. Environ Sci Technol 43, 597-603. 
Bergamasco, A. M., Eldridge, M., Sanseverino, J., Sodre, F. F., Montagner, C. C., Pescara, I. C., Jardim, W. F., Umbuzeiro Gde, A., 2011. Bioluminescent yeast estrogen assay (BLYES) as a sensitive tool to monitor surface and drinking water for estrogenicity. J Environ Monit 13, 3288-93.

Biederman, S., Tschudin, P., Grob, K., 2010. Transfer of bisphenol A from thermal printer paper to the skin. Anal Bioanal Chem 398, 571-6.

Brand, W., de Jongh, C. M., van der Linden, S. C., Mennes, W., Puijker, L. M., van Leeuwen, C. J., van Wezel, A. P., Schriks, M., Heringa, M. B., 2013. Trigger values for investigation of hormonal activity in drinking water and its sources using CALUX bioassays. Environ Int 55, 109-18.

Burkhardt-Holm, Patricia, 2010. Endocrine disruptors and water quality: a state-ofthe-art review. Int J Water Resour Dev 26, 477-493.

Carvalho, A. R. M., Cardoso, V. V., Rodrigues, A., Ferreira, E., Benoliel, M. J., Duarte, E. A., 2015. Occurrence and analysis of endocrine-disrupting compounds in a water supply system. Environ Monit Assess 187, 139. doi: 10.1007/s10661-015-4374-0.

Casajuana, N., Lacorte, S., 2003. Presence and release of phthalic esters and other endocrine disrupting compounds in drinking water. Chromatographia 57, 64955.

Chang, H. S., Choo, K. H., Lee, B., Choi, S. J., 2009. The methods of identification, analysis, and removal of endocrine disrupting compounds (EDCs) in water. J Hazard Mater 172, 1-12.

Cho, S. C., Bhang, S. Y., Hong, Y. C., Shin, M. S., Kim, B. N., Kim, J. W., Yoo, H. J., Cho, I. H., Kim, H. W., 2010. Relationship between environmental phthalate exposure and the intelligence of school-age children. Environ Health Perspect $118,1027-32$.

Colin, A., Bach, C., Rosin, C., Munoz, J. F., Dauchy, X., 2014. Is drinking water a major route of human exposure to alkylphenol and bisphenol contaminants in France? Arch Environ Contam Toxicol 66, 86-99. 
Conley, J. M., Evans, N., Mash, H., Rosenblum, L., Schenck, K., Glassmeyer, S., Furlong, E. T., Kolpin, D. W., Wilson, V. S., 2016. Comparison of in vitro estrogenic activity and estrogen concentrations in source and treated waters from 25 U.S. drinking water treatment plants. Sci Total Environ S0048-9697, 30303-5.

Connolly, L., Ropstad, E., Verhaegen, S., 2011. In vitro bioassays for the study of endocrine-disrupting food additives and contaminants. Trends Analyt Chem 30, 227-238.

De Jager, C., Aneck-Hahn, N. H., Barnhoorn, I. E. J., Bornman, M. S., Pieters, R., Van Wyk, J. H., Van Zijl, C., 2011. The compilation of a toolbox of bio-assays for detection of estrogenic activity in water. WRC report no 1816/1/10. Pretoria: Water Research Commission of South Africa.

Desbrow, C., Routledge, E. J., Brighty, G. C., Sumpter, J. P., Waldock, M., 1998. Identification of estrogenic chemicals in STW effluent. 1. Chemical fractionation and in vitro biological screening. Environ Sci Technol 32, 154958.

Dominguez-Morueco, N., Gonzalez-Alonso, S., Valcarcel, Y., 2014. Phthalate occurrence in rivers and tap water from central Spain. Sci Total Environ 500$501,139-46$.

Esteban, S., Gorga, M., González-Alonso, S., Petrovic, M., Barceló, D., Valcárcel, Y., 2014. Monitoring endocrine disrupting compounds and estrogenic activity in tap water from central Spain. Environ Sci Pollut Res 21, 9297-9310.

Falconer, I. R., Chapman, H. F., Moore, M. R., Ranmuthugala, G., 2006. Endocrinedisrupting compounds: a review of their challenge to sustainable and safe water supply and water reuse. Environ Toxicol 21, 181-91.

Fan, Z-L., Hu, J-Y., An, W., Yang, M., 2013. Detection and occurrence of chlorinated byproducts of bisphenol $A$, nonylphenol, and estrogens in drinking water of China: comparison to the parent compounds. Environ Sci Technol 47, 1084150. 
Galli, R., Braun, C., 2008. Integrative risk assessment of endocrine disruptors in Switzerland. Chimia 62, 417-23.

Genthe, B., Steyn, M., Aneck-Hahn, N. H., Van Zijl, C., De Jager, C., 2010. The feasibility of a health risk assessment framework to derive guidelines for oestrogen activity in treated drinking water. WRC Report No. 1749/1/09. Pretoria: Water Research Commission of South Africa.

Ghisari, M., Bonefeld-Jorgensen, E. C., 2009. Effects of plasticizers and their mixtures on estrogen receptor and thyroid hormone functions. Toxicol Lett $189,67-77$.

Gou, Yan-You, Lin, Susana, Que, Danielle E., Tayo, Lemmuel L., Lin, Ding-Yan, Chen, Kuan-Chung, Chen, Fu-An, Chiang, Pen-Chi, Wang, Gen-Shuh, Hsu, Yi-Chyuan, Chuang, Kuo Pin, Chuang, Chun-Yu, Tsou, Tsui-Chun, Chao, How-Ran, 2016. Estrogenic effects in the influents and effluents of the drinking water treatment plants. Environ Sci Pollut Res 23, 8518-8528.

Grun, F., Blumberg, B., 2009. Endocrine disruptors as obesogens. Mol Cell Endocr $304,19-29$.

Guillette, L. J., Crain, D. A., 2000. Environmental endocrine disrupters: an evolutionary perspective. New York: Taylor and Francis.

Hauser, R., Calafat, A. M., 2005. Phthalates and human health. Occup Environ Med 62, 806-18.

Heudorf, U., Mersch-Sundermann, V., Angerer, J., 2007. Phthalates: toxicology and exposure. Int J Hyg Environ Health 210, 623-34.

Hu, J-Y, Xie, G-H, Aizawa, T, 2002. Products of aqueous chlorination of 4nonylphenol and their estrogenic activity. Environ Toxicol Chem 21, 2034-9.

Johnson, A. C., Aerni, H. R., Gerritsen, A., Gibert, M., Giger, W., Hylland, K., Jürgens, M., Nakari, T., Pickering, A., Suter, M. J. F., Svenson, A., Wettstein, F. E., 2005. Comparing steroid estrogen, and nonylphenol content across a 
range of European sewage plants with different treatment and management practices. Water Research 39, 47-58.

Jugan, M. L., Oziol, L., Bimbot, M., Huteau, V., Tamisier-Karolak, S., Blondeau, J. P., Levi, Y., 2009. In vitro assessment of thyroid and estrogenic endocrine disruptors in wastewater treatment plants, rivers and drinking water supplies in the greater Paris area (France). Sci Total Environ 407, 3579-87.

Jurgens, M. D., Holthaus, K. I. E., Johnson, A. C., Smith, J. J. L., Hetheridge, M., Williams, R. J., 2002. The potential for estradiol and ethinylestradiol degradation in English rivers. Environ Toxicol Chem 21, 480-8.

Kawagoshi, Y., Fujita, Y., Kishi, I., Fukunaga, I., 2003. Estrogenic chemicals and estrogenic activity in leachate from municipal waste landfill determined by yeast two-hybrid assay. J Environ Monit 5, 269-74.

Kuch, H. M., Ballschmiter, K., 2001. Determination of endocrine-disrupting phenolic compounds and estrogens in surface and drinking water by HRGC-(NCl)-MS in the picogram per liter range. Environ Sci Technol 35, 3201-6.

Kunz, P. Y., Kienle, C., Carere, M., Homazava, N., Kase, R., 2015. In vitro bioassays to screen for endocrine active pharmaceuticals in surface and waste waters. $J$ Pharm Biomed Anal 106, 107-15.

Liu, Xiaowei, Shi, Jianghong, Bo, Ting, Li, Huiyuan, Crittenden, John C., 2015. Occurrence and risk assessment of selected phthalates in drinking water from waterworks in China. Environ Sci Pollut Res 22, 10690-10698.

Loos, R., Wollgast, J., Huber, T., Hanke, G., 2007. Polar herbicides, pharmaceutical products, perfluorooctanesulfonate (PFOS), perfluorooctanoate (PFOA), and nonylphenol and its carboxylates and ethoxylates in surface and tap waters around Lake Maggiore in Northern Italy. Anal Bioanal Chem 387, 1469-78.

Loyo-Rosales, J. E., Rosales-Rivera, G. C., Lynch, A. M., Price, C. P., Torrents, A., 2004. Migration of nonylphenol from plastic containers to water and a milk surrogate. J Agric Food Chem 52, 2016-2020. 
Luks-Betlej, K., Popp, P., Janoszka, B., Paschke, H., 2001. Solid-phase microextraction of phthalates from water. J Chromatogr A 938, 93-101.

Lv, X., Xiao, S., Zhang, G., Jiang, P., Tang, F., 2016. Occurrence and removal of phenolic endocrine disrupting chemicals in the water treatment processes. Sci Rep 6, 22860.

Maggioni, S., Balaguer, P., Chiozzotto, C., Benfenati, E., 2013. Screening of endocrine-disrupting phenols, herbicides, steroid estrogens, and estrogenicity in drinking water from the waterworks of 35 Italian cities and from PET-bottled mineral water. Environ Sci Pollut Res Int 20, 1649-60.

Manickum, T., John, W., 2014. Occurrence, fate and environmental risk assessment of endocrine disrupting compounds at the wastewater treatment works in Pietermaritzburg (South Africa). Sci Total Environ 468-469, 584-97.

Metcalfe, C., Hoque, M. E., Sultana, T., Murray, C., Helm, P., Kleywegt, S., 2014. Monitoring for contaminants of emerging concern in drinking water using POCIS passive samplers. Environ Sci Process Impacts 16, 473-81.

Metzler, M., Kulling, S. E., Pfeiffer, E., Jacobs, E., 1998. Genotoxicity of estrogens. Z Lebensm Unters Forsch A 206, 367-373.

Nakada, N., Nyunoya, H., Nakamura, M., Hara, A., Iguchi, T., Takada, H., 2004. Identification of estrogenic compounds in wastewater effluent. Environ Toxicol Chem 23, 2807-15.

NTP-CERHR, 2003. Monograph on the potential human reproductive and developmental effects of di-isononyl phthalate (DINP). National Toxicology Program, US Department of Health and Human Services. NIH Publication No. 03-4484, March 2003.

Omoruyi, I. M., Pohjanvirta, R., 2015. Estrogenic activity of wastewater, bottled waters and tap water in Finland as assessed by a yeast bio-reporter assay. Scand J Public Health 43, 770-5. 
Padhye, Lokesh P., Yao, Hong, Kung'u, Francis T., Huang, Ching-Hua, 2014. Yearlong evaluation on the occurrence and fate of pharmaceuticals, personal care products, and endocrine disrupting chemicals in an urban drinking water treatment plant. Water Res 51, 266-276.

Pan, G., Hanaoka, T., Yoshimura, M., Zhang, S., Wang, P., Tsukino, H., Inoue, K., Nakazawa, H., Tsugane, S., Takahashi, K., 2006. Decreased serum free testosterone in workers exposed to high levels of di-n-butyl phthalate (DBP) and di-2-ethylhexyl phthalate (DEHP): a cross-sectional study in China. Environ Health Perspect 114, 1643-8.

Racz, L., Goel, R. K., 2010. Fate and removal of estrogens in municipal wastewater. J Environ Monit 12, 58-70.

Rochester, J. R., 2013. Bisphenol A and human health: a review of the literature. Reprod Toxicol 42, 132-55.

Romero, J., Ventura, F., Gomez, M., 2002. Characterization of paint samples used in drinking water reservoirs: identification of endocrine disruptor compounds. J Chromatogr Sci 40, 191-7.

Routledge, E. J., Sumpter, J. P., 1996. Estrogenic activity of surfactants and some of their degradation products assessed using a recombinant yeast screen. Environ Toxicol Chem 15, 241-248.

Rudel, R. A., Melly, S. J., Geno, P. W., Sun, G., Brody, J. G., 1998. Identification of alkylphenols and other estrogenic phenolic compounds in wastewater, septage, and goundwater on Cape Cod, Massachusetts. Environ Sci Technol $32,861-9$.

Santana, J., Giraudi, C., Marengo, E., Robotti, E., Pires, S., Nunes, I., Gaspar, E. M., 2014. Preliminary toxicological assessment of phthalate esters from drinking water consumed in Portugal. Environ Sci Pollut Res Int 21, 1380-90.

Sax, L., 2010. Polyethylene terephthalate may yield endocrine disruptors. Environ Health Perspect 118, 445-8. 
Serodio, P., Nogueira, J. M., 2006. Considerations on ultra-trace analysis of phthalates in drinking water. Water Res 40, 2572-82.

Shao, B., Hu, J., Yang, M., An, W., Tao, S., 2005. Nonylphenol and nonylphenol ethoxylates in river water, drinking water, and fish tissues in the area of Chongqing, China. Arch Environ Contam Toxicol 48, 467-73.

Shi, Wei, Hu, Xinxin, Zhang, Fengxian, Hu, Guanjiu, Hao, Yingqun, Zhang, Xiaowei, Liu, Hongling, Wei, Si, Wang, Xinru, Giesy, John P., Yu, Hongxia, 2012. Occurrence of thyroid hormone activities in drinking water from eastern China: contributions of phthalate esters. Environ Sci Technol 46, 1811-1818.

Slabbert, J. L., Venter, E. A., Moletsane, M., Van Wyk, J. H., Blaise, C., Aneck-Hahn, N. H., 2008. An investigation of the estrogenic activity in water from selected drinking water treatment processes. WRC Report No. 1532/1/08. Pretoria: Water Research Commission of South Africa.

Soares, A., Guieysse, B., Jefferson, B., Cartmell, E., Lester, J. N., 2008. Nonylphenol in the environment: a critical review on occurrence, fate, toxicity and treatment in wastewaters. Environ Int 34, 1033-49.

Sodré, Fernando F., Locatelli, Marco Antonio F., Jardim, Wilson F., 2010. Occurrence of emerging contaminants in Brazilian drinking waters: a sewageto-tap issue. Water Air Soil Pollut 206, 57-67.

Stackelberg, P. E., Furlong, E. T., Meyer, M. T., Zaugg, S. D., Henderson, A. K., Reissman, D. B., 2004. Persistence of pharmaceutical compounds and other organic wastewater contaminants in a conventional drinking-water-treatment plant. Sci Total Environ 329, 99-113.

Stanford, B. D., Snyder, S. A., Trenholm, R. A., Holady, J. C., Vanderford, B. J., 2010. Estrogenic activity of US drinking waters: a relative exposure comparison. J Am Water Works Assoc 102, 55-65.

Sumpter, J. P., 2005. Endocrine disrupters in the aquatic environment: an overview. Acta Hydrochim Hydrobiol 33, 9-16. 
Tanaka, H., Yakou, Y., Takahashki, A., Higashitani, T., Komori, K., 2001. Comparison between estrogenicities estimated from DNA recombinant yeast assay and from chemical analyses of endocrine disruptors during sewage treatment. Water Sci Technol 43, 125-32.

Ternes, T. A., Kreckel, P., Mueller, J., 1999a. Behaviour and occurrence of estrogens inmunicipal sewage treatement plants - II. Aerobic batch experiments with activated sludge. Sci Total Environ 225, 91-9.

Ternes, T. A., Stumpf, M., Mueller, J., Haberer, K., Wilken, R. D., Servos, M., 1999b. Behavior and occurrence of estrogens in municipal sewage treatment plants-I. Investigations in Germany, Canada and Brazil. Sci Total Environ $225,81-90$.

Torres, Nádia Hortense, Aguiar, Mario Mamede, Ferreira, Luiz Fernando Romanholo, Américo, Juliana Heloisa Pinê, Machado, Ângela Maria, Cavalcanti, Eliane Bezerra, Tornisielo, Valdemar Luiz, 2015. Detection of hormones in surface and drinking water in Brazil by LC-ESI-MS/MS and ecotoxicological assessment with Daphnia magna. Environ Monit Assess 187, 379. doi: 10.1007/s10661-015-4626-z.

USEPA, 1992. Integrated Risk Information System (IRIS). Washington DC, USA: National Center for Environmental Assessment.

USEPA, 2000a. Bis(2-ethylhexyl)phthalate (DEHP) Fact Sheet, CAS 117-81-7. USA: United States Environmental Protection Agency.

USEPA, 2000b. Dibutyl Phthalate Fact Sheet, CAS 84-74-2. USA: United States Environmental Protection Agency.

USEPA, 2002. Bisphenol A, CAS 80-05-7. Integrated Risk Information System (IRIS). Washington DC, USA: National Center for Environmental Assessment.

USEPA, 2011. Exposure Factors Handbook: 2011 edition. Washington, DC: National Centre for Environmental Assessement. 
Waters. 2009. Oasis glass cartridges care and use manual [Online]. Milford, USA: Waters Corporation. Available: http://www.waters.com/waters/support.htm?lid=10103462\&type=USRM [Accessed 24 Dec 2014].

Wilson, V. S., Bobseine, K., Gray, L. E., Jr., 2004. Development and characterization of a cell line that stably expresses an estrogen-responsive luciferase reporter for the detection of estrogen receptor agonist and antagonists. Toxicol Sci 81, 69-77.

Wise, A., O'Brien, K., Woodruff, T., 2011. Are oral contraceptives a significant contributor to the estrogenicity of drinking water? . Environ Sci Technol 45, 51-60. 